\title{
Gut Microbiome-Brain Communications Regulate Host Physiology and Behavior
}

\author{
Sun Hye Lee and Claire B. de La Serre* \\ Department of Foods and Nutrition, University of Georgia, Athens, GA 30602, USA
}

Received: December 17, 2014; Accepted: April 13, 2015; Published: April 23, 2015

*Corresponding author: Claire B. de La Serre, Department of Foods and Nutrition, University of Georgia, Athens, GA 30602, USA, Tel: 706-542-

6977; Fax: 706-542-5059; E-mail: cdlserre@uga.edu

\begin{abstract}
The human gut microbiota contains more than 100 trillion bacteria that, under normal physiological conditions, have beneficial symbiotic interactions with the host. However, a growing body of evidence has shown that alternations in the composition and diversity of the gut microbiota, or dysbiosis, can influence the development and progress of metabolic and neurological disorders. Communication between the microbiota and the brain is a bidirectional system involving endocrine, metabolic (bacterial components and metabolites), immune, and neural pathways. Gut microbiota composition influences the signals transmitted from the gut to the brain. Alternatively, the brain utilizes similar mechanisms, in particular endocrine and neural signaling, to modulate the composition of the gut bacteria. In this review, we describe the recent evidence of gut microbiota interaction with the central nervous system to influence physiological and cognitive functions and the therapeutic potential of modulation of the gut microbiota composition.
\end{abstract}

Keywords: Gut microbiota; Gut-brain axis; Dysbiosis

\section{Gut Microbiota Composition}

The human microbiota contains as many as 100 trillion bacteria and there are 10 times more bacterial cells in our body than human cells [1]. Specific bacterial phyla reside in the different body habitats; Actinobacteria, Firmicutes and Proteobacteria for skin, Bacteroidetes, Firmicutes, Fusobacteria and Proteobacteria for the oral cavity, Bacteroidetes, Firmicutes, and Proteobacteria for the airway tract, Firmicutes for the urogenital tract and Bacteroidetes and Firmicutes for the gastrointestinal (GI) tract [2]. In the human GI tract, microbiota distribution is not spatially even; bacterial presence and diversity increase along the GI tract $[3,4]$. The gut microbiota is primarily composed of anaerobic bacteria; more than $90 \%$ of them belong to the Bacteroidetes and Firmicutes phyla with minor proportions of other phyla, including Proteobacteria [5].

\section{Alteration in Microbiota Composition or Dysbiosis}

Under normal physiological conditions the gut microbiota and its host have beneficial symbiotic interactions. The microbiota notably plays essential roles in the protection against epithelial cell injury [6], metabolic regulation [7], GI tract development [8], innate and adaptive immune responses, and absorption of nutrients $[9,10]$. Alterations in microbiota composition and dysregulation of the intestinal mucosa homeostasis have been implicated in the development and progression of pathologies. This compositional change in the microbiota and/ or an abnormality in the interactions between the host and the commensal microbiota is referred to as dysbiosis. Gut microbiota dysbiosis has been linked to chronic low-grade intestinal inflammation and acute intestinal autoimmunity diseases such as Irritable Bowel Syndrome (IBS) and Inflammatory Bowel Disease (IBD) $[11,12]$. Abnormal microbiota composition is associated with a wide range of metabolic and behavioral disorders, such as anxiety/depression [13-15], autism spectrum disorders [16-18], hepatic encephalopathy [19], multiple sclerosis [20, 21], allergies [22], visceral pain [23,24], atherosclerosis [25] and cardiovascular risks [26]. GI microbiota dysbiosis might also be involved in the development and persistence of systemic disorders [27]. For example, obesity has been characterized by a decrease in overall diversity [28] and an increase in Proteobacteria abundance and in the Firmicutes to Bacteroidetes ratio $[28,29]$ and microbiota composition is believed to influence energy balance and glucose homeostasis [30-32].

Evidence that changes in microbiota composition are correlated with metabolic and behavioral disorders has drawn attention to a potential causal role for the microbiota in pathologies and has led to the emergence of the 'microbiota-gutbrain axis' concept [33-35]. The gut-brain axis is a bidirectional communication system between the GI tract and the brain [36] via hormonal, immunological, and neural signaling. Information from the GI tract and the intestinal microbiota can reach the peripheral and Central Nervous System (CNS), concurrently the brain is able to influence GI functions such as motility and secretion but also immune responses and cytokine production [36,37].

\section{The Microbiota-Gut-Brain Axis}

The gut microbiota can modulate gut-brain axis signaling via direct and indirect mechanisms. The microbiota acts via endocrine, metabolic (bacterial components and metabolites), 
immune, and neural (vagal afferents and Enteric Nervous System (ENS)) pathways to modulate brain functions. For example, in a recent study by Duca et al, it was shown that the colonization of germ-free (GF) mice with obesity-prone microbiota remarkably increased the expressions of pro-inflammatory factors interleukin (IL)-6, TNF- $\alpha$, and Toll-Like Receptor 4 (TLR4) in the hypothalamus. In addition, colonization treatment affected the expressions of hypothalamic energy-regulating neuropeptides; reducing Proopiomelanocortin (POMC) and increasing AgoutiRelated Peptide (AgRP) and NeuroPeptide Y (NPY) expressions. The brain uses the same mechanisms to modulate the composition of the gut bacteria. For instance, under stressful conditions, the hypothalamus-pituitary-adrenal axis regulates the secretion of cortisol, which can have both local and systemic effects on immune cells secretion, including cytokines. Cortisol release can alter gut permeability and intestinal barrier functions, eventually leading to changes in gut microbiota composition [38,39].

Communication between the gut and the brain notably involves endocrine signaling. Enteroendocrine cells release gut peptides in response to enteric stimuli $[40,41]$. For example, cholecystokinin and gastrin are released in response to feeding to regulate appetite [42]. Enteroendocrine cells located in the epithelial lining possess specialized microvilli that project into the lumen. Consequently, these cells come into close contact with gut microbiota, enabling functional communication. In several studies, the gut microbiota was shown to influence the number of enteroendocrine cells and the release of gut peptides [43]. Cani et al. investigated the effect of prebiotic modulation of gut microbiota on intestinal permeability in leptin deficient (ob/ ob) mice by assessing changes in the microbial composition, intestinal permeability, gut peptides, and hepatic and systemic inflammation. The mice treated with the prebiotic carbohydrates (fermentable oligofructose) showed decreased endotoxemia and hepatic inflammation as well as improved intestinal barrier function and tight junction integrity. These effects were associated with increases in the endogenous Glucagon-Like Peptide-2 (GLP-2) production and are believed to be GLP-2dependent [44]. Moreover, colonization of GF animals with either a "lean" or an "obese" microbiota leads to replication of the donor phenotype $[45,46]$. GF rodents colonized with an obese-type microbiota notably exhibit a decrease in GI peptide expression, such as Glucagon-Like Peptide-1 (GLP-1) and Peptide YY (PYY) [46]. Changes in gut peptide secretion could modulate gut-tobrain neural signaling. Information between the gut and the brain is conveyed via the ENS. Vagal afferent neurons are notably in charge of transmitting sensory information from the GI tract to the CNS. Vagal signaling has been extensively studied in relation to feeding behavior and control of appetite; signals originating from the GI tract are conveyed via the vagus nerve to the Nucleus of Solitary Tract (NTS) in the brainstem and hypothalamus to regulate ingestive behavior [47]. Microbiota-induced changes in gut peptide expression have notably been associated with alterations in food intake [46].

While microbiota-driven changes in gut peptide secretion can affect gut-brain neural communication, there is evidence of a potential direct effect of bacteria on sensory pathways. Recent work has found that bacteria are able to produce neurotransmitters; bacterial colonization of GF mice resulted in over 2-fold increase in 5-hydroxytryptamine (5-HT) [48]. Specifically, commensal Lactobacilli and Bifidobacteria have been shown to produce $\gamma$-aminobutyric acid (GABA) [49] while Escherichia spp., Bacillus spp. and Saccharomyces spp. produce noradrenaline; Candida spp., Streptococcus spp., Escherichia spp., and Enterococcus spp. can produce 5-HT. Additionally, Bacillus spp. and Lactobacillus spp. can produce dopamine and acetylcholine, respectively [49,50]. There is growing evidence that vagal signaling is involved in microbiota-tobrain communication. Chronic treatment with L. rhamnosus in mice induced region-dependent changes of GABA expression in the brain and attenuated stress-related disorders, including anxiety and depression. However, these effects were blunted in vagotomized mice [13]. Similarly, Bercik et al. demonstrated that the anti-anxiety effect of $B$. longum involves vagal afferent signaling. Using a chemically induced colitis mouse model, they found that $B$. longum stabilized the anxiety-like behavior but the effect was absent in mice that were vagotomized. They proposed that anxiolytic effect of $B$. longum was attributed to its signaling to the CNS by activation of the vagal system at the level of the ENS [51].

\section{The Role of Microbiota-Derived Metabolites}

GI bacteria may modulate endocrine and neural signaling indirectly via release of metabolites and/or bacterial compounds. Short Chain Fatty Acids (SCFA) are produced by bacterial fermentation of non-digestible dietary polysaccharides; notably acetate, propionate, and butyrate [52] and have profound impacts on gut health [53-55]. Butyrate is the preferred source of energy for colonocytes over propionate, acetate, or glucose [52] and is also involved in cell proliferation and differentiation. Sodium butyrate has notably been shown in vivo to have preventive effects on colon cancer development [52]. Importantly, nutrient deficiency in the colon characterized by the absence of SCFA is associated with colitis, underlying the potential role of SCFA in regulating local inflammation [52]. SCFA are rapidly absorbed within the colon leading to an increase in $\mathrm{pH}$ in the distal colon, affecting mineral absorption, notably enhancing sodium absorption and calcium bioavailability [52]. Acetate and propionate are absorbed into portal circulation [56]. Acetate as a component of acetyl-CoA is believed to increase plasma cholesterol by contributing to cholesterol synthesis while propionate may decrease cholesterol levels by inhibiting acetate to acetyl-CoA conversion [57]. The decrease in the acetic acid-to-propionic acid ratio was suggested as a possible indicator of the hypolipidemic effect of prebiotics (inulin and fructooligosaccharides) [58]. Moreover, recent studies have demonstrated that SCFA act as endogenous ligands for two G protein-coupled receptors, free fatty acid receptor 2 (FFAR2) and 3 (FFAR3). They are expressed in the GI tract, liver, immunocytes, and adipocytes [59-61]. Acetate infusion in mice induced a decrease in circulating free fatty acids which was blunted in the FFAR2-knockout mice [62], suggesting that acetate acts via FFAR2 to control circulating free fatty acid levels and 
lipolysis. In addition, SCFA may also influence the regulation of feeding. Leptin expression is increased by SCFA infusion, leading to a decrease in food intake, but this effect was almost abolished by knockdown of FFAR3 [63]. Moreover, FFAR2 and FFAR3 activation has been shown to be involved in the production and release of gut peptides GLP-1 and PYY, resulting in decreased food intake $[64,65]$.

Additionally, we have recently demonstrated that Lipopolysaccharides (LPS), endotoxins from Gram-negative bacteria, affect vagal signaling to promote food intake [66]. Obesity is associated with chronic increase of circulating LPS, quoted as metabolic endotoxemia [67]. We have used miniosmotic pumps to mimic metabolic endotoxemia and found that infusion of low dose of LPS was sufficient to alter vagal afferent neuron protein levels, impairing leptin signaling and promoting overfeeding [66]. Known probiotics, such as Bifidobacterium spp. have been shown to improve mucosal barrier function and reduce endotoxin levels; these changes are associated with a reduction in energy intake [68].

Bacterial metabolites, notably bacterial fermentation products such as lactic and propionic acids, not only modulate host physiology but can impact behavior. Levels of lactic acid in the cecal contents were strongly associated with occurrence of anxiety and memory loss in rats fed a high fermentable carbohydrate diet [69]. Human studies also suggest a link between fermentation products and behavior. High fecal concentrations of propionic acid correlate with anxiety in patients with IBS [70]. Additionally, increased availability of substrates for microbial fermentation, such as carbohydrate maldigestion or malabsorption, has been shown to be associated with depression in female subjects [71].

Amino acids are also degraded by gut bacteria, notably tryptophan [72], a precursor of 5-HT [73]. A growing body of evidence indicates an association between the dysregulated kynurenine arm of tryptophan metabolism and many CNS and GI disorders [74]. Kynurenine is a product of tryptophan metabolism and has neuroactive and anxiogenic characteristics [75]. Conversely, another product of the tryptophan breakdown, kynurenic acid is considered to be neuroprotective. Indeed, reduced kynurenic acid to kynurenine ratio has been found in the major psychiatric disorders such as depression and schizophrenia [76]. Compositional shift in gut microbiota and subsequent alterations in serum levels of kynurenine could result in modifications of behavior and CNS response. For instance, the administration of a probiotic, L. johnsonii to diabetes-prone BioBreeding rats resulted in a decrease in serum kynurenine level [77]. Conversely, GF mouse colonization increased circulating levels of kynurenine and decreased expression of genes associated with neuronal development and function [78]. Taken together, these data suggest that metabolic products of gut microbiota could be involved in the modulation of the host's brain functions and behavior.

Expression of other genes involved in behavior has been shown to be under the influence of microbiota, notably Brain Derived Neurotropic Factor (BDNF). BDNF regulates multiple aspects of cognitive and emotional behaviors and its expression can be modulated by prebiotic supplementation. BDNF gene expression notably increased in rats when orally administrated with prebiotics, fructooligosaccharides and galactooligosaccharides for five weeks [79].

\section{Immunological Mechanisms}

Microbiota composition has direct effects on the host immune system at the levels of both innate and adaptive immunity $[80,81]$. First, the innate immune system is capable of sensing various types of bacterial components via Pattern Recognition Receptors (PRRs). PRRs recognize bacterial products like LPS, lipoproteins, and peptidoglycans and trigger the appropriate responses, such as the release of pro-inflammatory cytokines [82]. There are two types of PRRs, Toll-like receptors (TLRs) and Nod-like receptors (NLRs) $[83,84]$. TLRs are notably expressed on enterocytes and enteric neurons, including vagal afferent neurons [66,85-87]. TLR activation leads to activation of transcription factors, such as Nuclear Factor Kappa B (NFKB) to promote pro-inflammatory cytokine synthesis and secretion [88]. NOD activation also contributes to the onset of inflammatory responses and insulin resistance [89].

Additionally, a growing body of evidence shows that the gut microbiota coordinates $\mathrm{T}$ cell differentiation, enabling the full functioning of the acquired immune system. $\gamma \delta$ intraepithelial lymphocytes play a crucial role as inhibitors of bacterial penetration during intestinal injury [90]. $\gamma \delta$ T-helper (Th) cell differentiation can be regulated by the commensal microbiota. The microbiota is involved in generating adenosine 5' triphosphate, which then activates a subset of dendritic cells and contributes to Th17 differentiation [91]. Specifically, differentiation of Th17 cells in the lamina propria of the small intestine is correlated with the presence of bacteria from the Cytophaga-FlavobacteriumBacteroides group [92]. Additionally, the stimulation of TLR5, mediated by flagellin, triggers the expression of IL- 6 , inducing Th17 cell programming [93]. Moreover, polysaccharide A from $B$. fragilis can protect from inflammatory diseases such as colitis by suppressing pro-inflammatory IL-17-producing CD4+ $\mathrm{T}$ cells and inducing IL-10-producing CD4+ $\mathrm{T}$ cells [94].

The crucial role of the microbiota in host immunity has been demonstrated with GF animal models. GF mice display defective gut-associated lymphoid tissues, the first class of intestinal defense, less cellular lamina propria, smaller and less mesenteric lymph nodes [95,96], and a reduced number of intraepithelial lymphocytes compared to the colonized animals [97,98]. They also showed decreased expressions of TLRs and class II major histocompatibility complex proteins, which act as pathogen sensors and antigen presenters, respectively [99,100]. Normal activation of TLRs appears to be critical not only for appropriate immune signaling, but also for host physiology. For example, TLR5 mainly recognizes bacterial flagellin [101] and TLR5-knockout mice exhibited profound metabolic disturbances manifested as obesity, dyslipidemia, hypertension, and insulin resistance [102].

As the proper maintenance of the gut microbiota contributes to both immunological and metabolic balances [103], dysbiosis 
may result in the dysregulation of both systems [104]. Indeed, over-activation of PRRs induced by the intestinal microbial alterations and the resulting low-grade inflammation seem to play a crucial role in the development of obesity. Recent work focusing on bacterial LPS has demonstrated that metabolic endotoxemia and the subsequent activation of TLR4 are involved in the development of type 2 diabetes and cardiovascular diseases by contributing to low-grade inflammation and disrupting energy regulation $[66,105,106]$. Chronic LPS injections in animal models are sufficient to induce weight gain and insulin resistance, pointing to a potential causal role for bacterial products and altered immune response in obesity and related metabolic disturbances $[66,67]$.

Microbiota modulation of the host immune response may also affect brain functions and behavior. Human [107] and animal $[108,109]$ studies have shown that changes in microbiota composition affect circulating systemic cytokine levels via activation of TLRs [110].

Pro-inflammatory cytokines, such as IL-4, have been reported to be associated with a series of psychiatric disorders [111]. In addition, Desbonnet et al. have studied in rats the effect of probiotics on anxiety behaviors associated with maternal separation and have found that administration of probiotics B. infantis 35624 decreased IL-6 secretion and improved depression-like behavior in pups [109].

\section{Descending Signals from the Brain Can Modulate Microbiota Composition}

The gut-brain axis is a bidirectional communication route. For example, vagal efferent neurons send motor information from the brain to the periphery [112] and central signaling can affect gut microbiota composition to modulate host physiology. The brain-gut microbiota axis is mediated via endocrine and neural pathways in both direct and indirect manners [38,113,114].

Central modulation of satiety plays a crucial role in the braingut microbiota pathway. The CNS is involved in controlling food intake and food preferences and resulting changes in nutrient availability for gut microbiota can lead to alteration of microbial composition. In addition, central neuropeptides such as POMC or GLP-1 are involved not only in regulating hunger and satiety, but also in GI secretion and motility [115]. This downward regulation is mediated via the vagal efferent neurons, notably for GI motility [113]. Changes in GI transit have been shown to modify microbiota composition [116]. In mice, administration of polyethylene glycol decreases gastrointestinal transit time and is associated with changes in microbiota composition, notably a decrease in the relative abundance of families Peptococcaceae, Eubacteriaceae, and Anaeroplasmataceae and an increase in families Bacteroidaceae and Peptostreptococcaceae. Similar changes can be induced via dietary manipulation of gastric motility [116]. Altered profile of gut microbiota has been linked to diseases such as IBD, which are associated with changes in GI motility [117].

The Hypothalamus-Pituitary-Adrenal (HPA) axis is known to mediate stress and anxiety responses that can influence intestinal metabolism, including gut motility and secretion, leading to environmental changes for gut microbiota [38]. A recent study demonstrated that social disruption, as a source of stress, caused dramatic changes in the gut microbiota composition in adult mice. Mice subjected to stress exhibited an increase in Clostridium spp. and a decrease in Bacteroides spp. The alteration in microbial composition was followed by increased levels of circulating inflammatory cytokines such as IL-6 and Monocyte Chemoattractant Protein 1 (MCP1) and caused increased bacterial translocation [118]. In their previous study, the authors also showed that the secondary lymphoid organs were involved in the stress-induced increase in bacterial translocation [119]. In rats, stress has also been shown to disrupt GI epithelial barrier integrity, leading to mast cell activation in the mucosa [120]. Moreover, it has been shown that early life exposure to stress, such as maternal separation, is associated with increased levels of corticosterone and immune response and altered microbiota in rat feces. These changes were associated with significant increases in the pro-inflammatory cytokines TNF- $\alpha$, IL-6, and Interferon- $\gamma$ (IFN- $\gamma)$ [121]. This is particularly interesting as recent work has established that early perturbations in GI microbiota are persistent in adulthood [122]. While the pathways linking stress to microbiota composition remain unclear, there is evidence of direct neural communication between the host and its microbiota. The QseCsensor kinase, a bacterial adrenergic receptor, has recently been identified as a microbial receptor for epinephrine and norepinephrine directly originating from the host [114].

\section{Microbiota Modulation as Therapeutic Strategies against Dysbiosis}

Alterations in microbiota composition lead to changes in endocrine, neural, and immune signals from the GI tract and this information is then conveyed to the CNS [38]. Alternatively, central signals can modulate GI functions and microbiota composition [27]. Therefore, in a dysbiotic state, this bidirectional communication can lead to a worsening of the situation and several strategies have been developed to stop or attenuate this potential vicious circle. A growing body of evidence shows that alternations in the composition and diversity of the gut microbiota have a substantial influence on the pathophysiology of metabolic and CNS disorders, and consequently there has been a growing attention to microbiota manipulation.

\section{Probiotics}

One approach is the use of probiotics. "Probiotics are live microorganisms which when administered in adequate amounts confer health benefits on the host" [123]. Among several mechanisms for actions of probiotics, probiotics exhibit beneficial effects on the host through the modulation of the intestinal microbial composition by suppressing pathogenic bacteria such as clostridia and increasing or protecting beneficial populations such as bifidobacteria [124]. Probiotics inhibit growth of enteric pathogens by direct antimicrobial actions via production of inhibitory substances, immunomodulation via 
immune cell stimulation, competitive exclusion via blocking of epithelial binding receptors, and improvement of epithelial barrier integrity via mucin and defensins $[125,126]$.

Probiotics can exert a direct antimicrobial ability by producing inhibitory substances such as organic acids and bacteriocins, peptides with a potent antibacterial property $[127,128]$. Lactobacillus and Bifidobacterium spp. exhibited antiinfective effects against enterohemorrhagic E. coli 0157:H7 in human intestinal cells by producing lactic acid and subsequently decreasing luminal pH [129,130]. Additionally, Corr et al. demonstrated that L. Salivarius UCC118 protected mice from the invasive foodborne pathogen L. monocytogenes via stimulation of bacteriocins [130].

Probiotic bacteria can also act as immunomodulatory agents to alleviate the inflammatory response to infection in the host GI tract $[131,132]$. They can substantially reduce proinflammatory cytokine secretions such as TNF-a and IFN- $\gamma$, while stimulating anti-inflammatory cytokines such as IL-10 and TGF- $\beta[131,133,134]$. B. breve and $S$. thermophilus have been shown to produce metabolites which inhibit TNF-a secretion from peripheral blood mononuclear cells [131,133-135]. Some probiotic strains induce secretory Immunoglobulin A (IgA) production, leading to activation of regulatory $\mathrm{T}$ (Treg) and dendritic cells [136]. For example, the oral administration of L. casei to BALB/c mice induced activation of the gut mucosal immune system by increasing the level of IgA ${ }^{+}$cells [137].

Some probiotic bacteria can compete with pathogens for binding sites to the mucous layer or epithelial cells, inhibiting the effect of pathogenic bacteria on epithelial cells $[138,139]$. Surface-layer proteins are located outside the bacterial cell wall and are involved in tissue adherence. In a study using human epithelial (HEp-2 and T84) cells, surface-layer protein extracts from L. helveticus blocked the adherence of E. coli 0157:H7 to epithelial cells [140].

In addition, probiotics are capable of improving epithelial barrier integrity by inducing the expression of mucin from the host [141]. Mucin, as the primary component of the mucosal layer in the GI tract, protects the intestinal epithelium from pathogenic invasion by forming a defensive physicochemical barrier [142]. In an in vitro study using the Caco-2 cell line, L. casei GG was shown to induce MUC2 expression, inhibiting bacterial translocation to the intestinal epithelium [141]. Some probiotics can also stimulate the release of defensins, which play a role in stabilization of epithelial barrier function as antimicrobial peptides [143]. Several probiotic strains were found to strengthen intestinal barrier function in the Caco- 2 cell line by up-regulating the expression of human $\beta$-defensin 2 through induction of mitogenactivated protein kinases. They include B. longum, B. infantis, B. breve, L. acidophilus, L. casei, L. delbrueckii ssp. bulgaricus, $L$. plantarum, and Streptococcus salivarius ssp. thermophilus [144].

Experimental and clinical studies have found that probiotics have therapeutic effects on metabolic diseases. For example, the administration of dual probiotic strains (L. curvatus HY7601 and L. plantarum KY1032) to diet-induced obese mice led to not only reduced body weight gain and fat accumulation in adipose tissue, but also decreased levels of plasma insulin, leptin, and total cholesterol [145]. Pro-inflammatory genes (including TNF- $\alpha$, IL-6, IL1 $\beta$ and MCP1) were down-regulated in adipose tissue and fatty acid oxidation-related genes were up-regulated in the liver [145]. The reduction of cytokine expressions in probiotic-treated mice may be explained by a decreased release of pro-inflammatory LPS [146]. As mentioned before [141144], probiotic bacteria improve intestinal barrier integrity, thereby decreasing LPS translocation to the periphery and leading to reduced production of pro-inflammatory cytokines in adipose tissue. Similarly, it has been recently established that L. rhamnosus GG (LGG) displays anti-obesity and antidiabetic effects when administered to high-fat diet-fed mice $[147,148]$. Oral administration with LGG for 13 weeks notably led to increased expression of fatty acid oxidation genes in the liver and decreased expression of gluconeogenic genes. LGG treatment also increased glucose transporter-4 gene expression in skeletal muscle and adiponectin production in adipose tissue $[147,148]$. In a clinical setting, B. infantis 35624 was orally administrated for 6 to 8 weeks to patients with gastrointestinal (ulcerative colitis) or non-gastrointestinal (chronic fatigue syndrome, psoriasis) disorders [149]. The results showed that levels of plasma C - Reactive Protein (CRP) and pro-inflammatory cytokines (TNF-a and IL-6) were significantly reduced in three inflammatory disorders compared with placebo. Furthermore, $B$. infantis 35624 significantly decreased LPS-stimulated secretion of TNF- $\alpha$ and IL-6 in B. infantis 35624-treated healthy subjects compared with the placebo group. Thus, it was concluded that the beneficial effects of $B$. infantis 35624 are applicable both locally (gastrointestinal) and systemically [149].

In addition to physiological effects, there is evidence suggesting that the use of probiotics can be applied to the treatment of psychiatric conditions [150]. The beneficial effects of probiotics on psychopathological disturbances may be explained by reduction in pro-inflammatory cytokines, competitive exclusion of pathogenic bacteria, and interaction with the CNS, resulting in changes in levels or functions of neurotransmitters [151-154]. The findings of the possible association of anxiety or depression with elevated levels of pro-inflammatory factors (TNF- $\alpha$, IL-6, and CRP) indicate the involvement of inflammatory factors in psychological conditions [155]. Cytokine receptors located on peripheral nerves, including the vagal nerve, may convey inflammatory signaling to the brain, which possibly evokes psychologically unstable states such as anxiety and depression [156]. Several studies have demonstrated that Lactobacillus and Bifidobacterium strains alleviate inflammatory responses in rodents $[108,157,158]$. Desbonnet et al. found that the administration of probiotics $B$. infantis for 14 days improved depression-like behavior in rats with a significant attenuation in pro-inflammatory cytokines IFN- $\gamma$, TNF-a, and IL-6 [108]. Additionally, in rats subjected chronically to the forced swim test, $B$. infantis administration triggered a significant increase in plasma tryptophan concentration, known as a serotonergic precursor [108]. Another probiotic, L. paracasei, has been shown to produce neurotransmitter GABA [159]. In addition, probiotics 
can also exert anti-stress effects by decreasing the level of cortisol, a well-characterized stress hormone [160]. For example, a study investigating potential synergic effects of L. helveticus and $B$. longum administration showed that probiotic treatment attenuated anxiety- and depression-related behaviors as well as levels of serum cortisol in both rats and human subjects [161].

Taken together, these data show that certain probiotic strains can modulate various aspects of metabolic and behavioral functions. However, further experimental and clinical trials are required to identify the exact mechanisms and pathways mobilized by probiotics.

\section{Prebiotics}

In addition to probiotics, modulation of gut microbiota composition can be mediated with prebiotics. Prebiotics are "non-digestible food ingredients that beneficially affect the host by selectively stimulating the growth or activity of one of a limited number of bacterial species, thus improving host health" [162]. Chronic administration of prebiotics such as oligofructose to genetic (ob/ob) or diet-induced obese and diabetic mice increases the expression of intestinal proglucagon and circulating GLP-1, improves glucose homeostasis and leptin sensitivity, and decreases oxidative stress, low-grade inflammation, and fatmass accumulation [163]. These metabolic improvements are associated with compositional shift of specific gut microbiota phyla, specifically, decreased Firmicutes and increased Bacteroidetes [119]. Additionally, administration of oligofructose restores A. muciniphila abundance, which is associated with improved metabolic states [164]. Similarly, oligofructose administered to diet-induced obese rats reduces fat mass and weight gain with a noticeable increase in bifidobacteria and lactobacilli [165]. Importantly, oligofructose supplementation has been shown to promote weight loss in overweight and obese humans as well [166]. Another prebiotic, honey, a natural oligosaccharide-rich product, is shown to improve glycemic control in streptozotocin-induced diabetic rats [167]. It is believed that pancreatic $\beta$-cells are vulnerable to oxidative stress due to the relatively low levels of antioxidant enzymes in the pancreas, which may play a crucial role in the $\beta$-cell deterioration frequently characterized in diabetes $[168,169]$. In rat models with diabetes, honey supplementation was shown to decrease oxidative stress in the pancreas [170]. In addition to affecting metabolic outcomes, the daily use of prebiotics for three weeks in humans has been shown to reduce the cortisol stress response and improve emotional processing [171].

\section{Fecal Microbiota Transplant (FMT)}

FMT refers to "the process of instilling a liquid suspension of stool from a healthy donor into the patient's upper gastrointestinal tract through a nasogastric/nasoduodenal catheter or gastroscopy, or into the colon through a colonoscopy or a rectal catheter" [172]. It has been used for more than 50 years primarily for the treatment of $C$. difficile infection, but recently, there has been a growing interest in utilizing this bacteriotherapy for metabolic syndrome [173]. In related trials, FMT recipients showed more diversity and more similarity to the donor in composition of the fecal microbiota after transplantation with an increased proportion of Bacteroidetes and decreased proportion of Proteobacteria [5]. Moreover, Vrieze et al. have reported that insulin sensitivity of recipients with metabolic syndrome increased 6 weeks after infusion of intestinal microbiota from lean donors [173]. The therapeutic effects of FMT also can be applicable to other disorders, such as Parkinson's disease [174], chronic fatigue syndrome [175], and childhood regressive autism [176].

\section{Bariatric Surgery}

Bariatric surgery (weight loss surgery) is the most effective treatment for morbid obesity and is considered when other attempts have failed. The procedure facilitates a marked weight loss and improves metabolic parameters, including insulin sensitivity, pancreatic $\beta$-cell function, and inflammatory status as well as cardiovascular risk factors $[177,178]$. Reduced food reservoir and malabsorption have been suggested as possible mechanisms underlying the health-promoting influences of bariatric surgery, but a growing body of evidence suggests a beneficial role of altered gut microbiota profile following the surgery [179]. Indeed, certain procedures such as the Roux-en-Y Gastric Bypass [RYGB] have been reported in humans and animals to cause a marked increase in Gammaproteobacteria, decrease in Firmicutes, and loss of methanogen bacteria [179], which are associated with metabolic improvements after treatment $[180,181]$. The RYGB surgery in rats with normal weight caused a decrease in Firmicutes with significantly higher proportion of Proteobacteria compared to the control rats treated with sham operation [182]. Additionally, abundance of the butyrateproducing F. Prausnitzii species, considered to reduce low-grade inflammation, was increased following RYGB in the study.

\section{Conclusion}

A growing body of experimental and clinical evidence shows the potential involvement of the gut microbiota with metabolic and neuropsychiatric disorders and has drawn attention to the concept of 'microbiota-gut-brain axis'. The gut microbiota can modulate gut-brain axis signaling via endocrine, metabolic, immune and neural mechanisms.

Similarly, the same pathways are used by the brain to modulate the composition of the intestinal microbiota. However, in a dysbiotic state, this bidirectional communication can lead to the pathophysiological progress of metabolic and CNS disorders, and consequently there has been a growing attention to microbiome-based therapeutics, ranging from probiotics, prebiotics, fecal microbiota transplant to bariatric surgery. Still, there are unknowns regarding the role of the gut microbiota in metabolic and CNS disorders to be addressed prior to further development of new therapeutics. First, we need specific identification of potential mechanisms or pathways by which microbiota manipulation can affect the host physiology and psychology. Second, it is crucial to clarify the influence of maternal gut microbiota and infant nutrition on the microbial development in early childhood and throughout adulthood. Third, the impact of variation in the gut microbiota needs to be elucidated on drug 
metabolism, bioavailability, and toxicity as well as on microbiotagut-brain communication. This could be approached with the use of GF animals and ones colonized with existing microbial strains to determine the effect of specific bacteria on host physiology and related therapeutic strategies. Overall, further understanding of the interaction of the microbiota-gut-brain axis with the host's metabolism will guarantee more successful and promising improvements in the treatment of metabolic and CNS diseases.

\section{References}

1. Qin J, Li R, Raes J, Arumugam M, Burgdorf KS, Manichanh C, et al. A human gut microbial gene catalogue established by metagenomic sequencing. Nature. 2010; 464(7285): 59-65. doi: 10.1038/ nature 08821

2. Belkaid Y, Naik S. Compartmentalized and systemic control of tissue immunity by commensals. Nat Immunol. 2013; 14(7): 646-53. doi: 10.1038/ni.2604.

3. Brown EM, Sadarangani M, Finlay BB. The role of the immune system in governing host-microbe interactions in the intestine. Nat Immunol. 2013; 14(7): 660-7. doi: 10.1038/ni.2611.

4. Sekirov I, Russell SL, Antunes LC, Finlay BB. Gut microbiota in health and disease. Physiol Rev. 2010; 90(3): 859-904. doi: 10.1152/ physrev.00045.2009.

5. Turnbaugh PJ, Ley RE, Mahowald MA, Magrini V, Mardis ER, Gordon JI. An obesity-associated gut microbiome with increased capacity for energy harvest. Nature. 2006; 444(7122): 1027-31.

6. Rakoff-Nahoum S, Paglino J, Eslami-Varzaneh F, Edberg S, Medzhitov R. Recognition of commensal microflora by toll-like receptors is required for intestinal homeostasis. Cell. 2004; 118(2): 229-41.

7. Stappenbeck TS, Hooper LV, Gordon JI. Developmental regulation of intestinal angiogenesis by indigenous microbes via Paneth cells. Proc Natl Acad Sci U S A. 2002; 99(24):15451-5.

8. Hooper LV, Gordon JI. Commensal host-bacterial relationships in the gut. Science. 2001; 292(5519): 1115-8.

9. Backhed F, Ley RE, Sonnenburg JL, Peterson DA, Gordon JI. Hostbacterial mutualism in the human intestine. Science. 2005; 307(5717): 1915-20.

10. Ben XM, Li J, Feng ZT, Shi SY, Lu YD, Chen R. Low level of galactooligosaccharide in infant formula stimulates growth of intestinal Bifidobacteria and Lactobacilli. World J Gastroenterol. 2008; 14(42): 6564-8.

11. Collins SM, Denou E, Verdu EF, Bercik P. The putative role of the intestinal microbiota in the irritable bowel syndrome. Dig Liver Dis. 2009; 41(12): 850-3. doi: 10.1016/j.dld.2009.07.023.

12. Round JL, Mazmanian SK. The gut microbiota shapes intestinal immune responses during health and disease. Nat Rev Immunol. 2009; 9(5): 313-23. doi: 10.1038/nri2515.

13. Bravo JA, Forsythe P, Chew MV, Escaravage E, Savignac HM, Dinan TG Ingestion of Lactobacillus strain regulates emotional behavior and central GABA receptor expression in a mouse via the vagus nerve. Proc Natl Acad Sci U S A. 2011; 108(38): 16050-5. doi: 10.1073/ pnas.1102999108.

14. Diaz Heijtz R, Wang S, Anuar F, Qian Y, Bjorkholm B, Samuelsson A. Normal gut microbiota modulates brain development and behavior. Proc Natl Acad Sci U S A. 2011; 108(7): 3047-52. doi: 10.1073/ pnas.1010529108.
15. Foster JA, McVey Neufeld KA. Gut-brain axis: how the microbiome influences anxiety and depression. Trends Neurosci. 2013; 36(5): 305-12. doi: 10.1016/j.tins.2013.01.005.

16. Adams JB, Johansen LJ, Powell LD, Quig D, Rubin RA. Gastrointestinal flora and gastrointestinal status in children with autism--comparisons to typical children and correlation with autism severity. BMC Gastroenterol. 2011; 11: 22. doi: 10.1186/1471-230X-11-22.

17. de Theije CG, Wu J, da Silva SL, Kamphuis PJ, Garssen J, Korte SM. Pathways underlying the gut-to-brain connection in autism spectrum disorders as future targets for disease management. Eur J Pharmacol. 2011; 668 Suppl 1: S70-80. doi: 10.1016/j.ejphar.2011.07.013.

18. Thomas RH, Meeking MM, Mepham JR, Tichenoff L, Possmayer F, Liu S. The enteric bacterial metabolite propionic acid alters brain and plasma phospholipid molecular species: further development of a rodent model of autism spectrum disorders. J Neuroinflammation. 2012; 9: 153. doi: 10.1186/1742-2094-9-153 9:153.

19. Bajaj JS, Ridlon JM, Hylemon PB, Thacker LR, Heuman DM, Smith S. Linkage of gut microbiome with cognition in hepatic encephalopathy. Am J Physiol Gastrointest Liver Physiol. 2012; 302(1): G168-75. doi: 10.1152/ajpgi.00190.2011.

20.Berer K, Mues M, Koutrolos M, Rasbi ZA, Boziki M, Johner C. Commensal microbiota and myelin autoantigen cooperate to trigger autoimmune demyelination. Nature. 2011; 479(7374): 538-41. doi: 10.1038/nature10554.

21. Lee YK, Menezes JS, Umesaki Y, Mazmanian SK. Proinflammatory T-cell responses to gut microbiota promote experimental autoimmune encephalomyelitis. Proc Natl Acad Sci U S A. 2011; 108 Suppl 1: 461522. doi: $10.1073 /$ pnas. 1000082107 .

22. Rautava S, Isolauri E. The development of gut immune responses and gut microbiota: effects of probiotics in prevention and treatment of allergic disease. Curr Issues Intest Microbiol. 2002; 3(1): 15-22.

23. McKernan DP, Fitzgerald P, Dinan TG, Cryan JF. The probiotic Bifidobacterium infantis 35624 displays visceral antinociceptive effects in the rat. Neurogastroenterol Motil. 2010; 22(9): 1029-35, e268. doi: 10.1111/j.1365-2982.2010.01520.x.

24.Wang B, Mao YK, Diorio C, Wang L, Huizinga JD, Bienenstock J, et al. Lactobacillus reuteri ingestion and IK(Ca) channel blockade have similar effects on rat colon motility and myenteric neurones. Neurogastroenterol Motil. 2010; 22(1): 98-107, e33. doi: 10.1111/j.1365-2982.2009.01384.x.

25. Karlsson FH, Fak F, Nookaew I, Tremaroli V, Fagerberg B, Petranovic D, et al. Symptomatic atherosclerosis is associated with an altered gut metagenome. Nat Commun. 2012; 3: 1245. doi: 10.1038/ ncomms 2266.

26. Tang WH, Wang Z, Levison BS, Koeth RA, Britt EB, Fu X, et al. Intestinal microbial metabolism of phosphatidylcholine and cardiovascular risk. N Engl J Med. 2013; 368(17): 1575-84. doi: 10.1056/NEJMoa1109400.

27. Barbara G, Brummer, R.J., and Delzenne, N. Investigating the crosstalk between the gut microbiota and the host: the gut-brain axis. Consensus Report. Warsaw. 2007.

28. Turnbaugh PJ, Hamady M, Yatsunenko T, Cantarel BL, Duncan A, Ley $\mathrm{RE}$ et al. A core gut microbiome in obese and lean twins. Nature. 2009; 457(7228): 480-4. doi: 10.1038/nature07540.

29. Ley RE, Turnbaugh PJ, Klein S, Gordon JI. Microbial ecology: human gut microbes associated with obesity. Nature. 2006; 444(7122): 1022-3.

30. Qin J, Li Y, Cai Z, Li S, Zhu J, Zhang F, et al. A metagenome-wide 
association study of gut microbiota in type 2 diabetes. Nature. 2012; 490(7418): 55-60. doi: 10.1038/nature11450.

31. Migrenne S, Marsollier N, Cruciani-Guglielmacci C, Magnan C. Importance of the gut-brain axis in the control of glucose homeostasis. Curr Opin Pharmacol. 2006; 6(6): 592-597.

32. Sam AH, Troke RC, Tan TM, Bewick GA. The role of the gut/brain axis in modulating food intake. Neuropharmacology. 2012; 63(1): 46-56. doi: 10.1016/j.neuropharm.2011.10.008.

33. Rhee SH, Pothoulakis C, Mayer EA. Principles and clinical implications of the brain-gut-enteric microbiota axis. Nat Rev Gastroenterol Hepatol. 2009; 6(5): 306-14. doi: 10.1038/nrgastro.2009.35.

34. Cryan JF, O'Mahony SM. The microbiome-gut-brain axis: from bowel to behavior. Neurogastroenterol Motil. 2011; 23(3): 187-92. doi: 10.1111/j.1365-2982.2010.01664.x.

35. Claesson MJ, Jeffery IB, Conde S, Power SE, O'Connor EM, Cusack S, et al. Gut microbiota composition correlates with diet and health in the elderly. Nature. 2012; 488(7410): 178-84. doi: 10.1038/nature11319.

36. Mayer EA. Gut feelings: the emerging biology of gut-brain communication. Nat Rev Neurosci. 2011; 12 (8): 453-66. doi: 10.1038/ nrn3071.

37. Tracey KJ. Reflex control of immunity. Nat Rev Immunol. 2009; 9(6): 418-28. doi: 10.1038/nri2566.

38. Cryan JF, Dinan TG. Mind-altering microorganisms: the impact of the gut microbiota on brain and behaviour. Nat Rev Neurosci. 2012; 13(10): 701-12. doi: 10.1038/nrn3346.

39. Grenham S, Clarke G, Cryan JF, Dinan TG. Brain-gut-microbe communication in health and disease. Front Physiol. 2011; 2: 94. doi: 10.3389/fphys.2011.00094.

40. Cameron J, Doucet E. Getting to the bottom of feeding behaviour: who's on top? Appl Physiol Nutr Metab. 2007; 32(2): 177-89.

41. Wren AM, Bloom SR. Gut hormones and appetite control. Gastroenterology. 2007; 132(6): 2116-30.

42. Crowell MD, Wessinger SB. 5-HT and the brain-gut axis: opportunities for pharmacologic intervention. Expert Opin Investig Drugs. 2007; 16(6):761-5.

43. Uribe A, Alam M, Johansson O, Midtvedt T, Theodorsson E. Microflora modulates endocrine cells in the gastrointestinal mucosa of the rat. Gastroenterology. 1994; 107(5):1259-69.

44. Cani PD, Possemiers S, Van de Wiele T, Guiot Y, Everard A, et al. Changes in gut microbiota control inflammation in obese mice through a mechanism involving GLP-2-driven improvement of gut permeability. Gut. 2009; 58(8): 1091-103. doi: 10.1136/gut.2008.165886.

45. Ridaura VK, Faith JJ, Rey FE, Cheng J, Duncan AE, Kau AL, et al. Gut microbiota from twins discordant for obesity modulate metabolism in mice. Science. 2013; 341(6150): 1241214. doi: 10.1126/ science.1241214.

46. Duca FA, Sakar Y, Lepage P, Devime F, Langelier B, Dore J et al Replication of obesity and associated signaling pathways through transfer of microbiota from obese-prone rats. Diabetes. 2014; 63(5): 1624-36. doi: 10.2337/db13-1526.

47. Murphy KG, Bloom SR. Gut hormones and the regulation of energy homeostasis. Nature. 2006; 444(7121): 854-9.

48. Wikoff WR, Anfora AT, Liu J, Schultz PG, Lesley SA, Peters EC, et al Metabolomics analysis reveals large effects of gut microflora on mammalian blood metabolites. Proc Natl Acad Sci U S A. 2009;
106(10): 3698-703. doi: 10.1073/pnas.0812874106.

49. Barrett E, Ross RP, O'Toole PW, Fitzgerald GF, Stanton C. gammaAminobutyric acid production by culturable bacteria from the human intestine. J Appl Microbiol. 2012; 113(2): 411-7. doi: 10.1111/j.13652672.2012.05344.x

50. Lyte M. Probiotics function mechanistically as delivery vehicles for neuroactive compounds: Microbial endocrinology in the design and use of probiotics. Bioessays. 2011; 33(8): 574-81. doi: 10.1002/ bies.201100024.

51. Bercik P, Park AJ, Sinclair D, Khoshdel A, Lu J, Huang X, et al. The anxiolytic effect of Bifidobacterium longum NCC3001 involves vagal pathways for gut-brain communication. Neurogastroenterol Motil. 2011; 23(12): 1132-9. doi: 10.1111/j.1365-2982.2011.01796.x.

52. Wong JM, de Souza R, Kendall CW, Emam A, Jenkins DJ. Colonic health: fermentation and short chain fatty acids. J Clin Gastroenterol. 2006. 40(3): 235-43.

53. Tremaroli V, Backhed F. Functional interactions between the gut microbiota and host metabolism. Nature. 2012; 489(7415): 242-9. doi: $10.1038 /$ nature11552.

54. Hamer HM, Jonkers D, Venema K, Vanhoutvin S, Troost FJ, Brummer RJ. Review article: the role of butyrate on colonic function. Aliment Pharmacol Ther. 2008; 27(2): 104-119.

55. Topping DL, Clifton PM. Short-chain fatty acids and human colonic function: roles of resistant starch and nonstarch polysaccharides. Physiol Rev. 2001; 81(3): 1031-64.

56. Maslowski KM, Mackay CR. Diet, gut microbiota and immune responses. Nat Immunol. 2011; 12(1): 5-9. doi: 10.1038/ni0111-5.

57. Harris K, Kassis A, Major G, Chou CJ. Is the gut microbiota a new factor contributing to obesity and its metabolic disorders? J Obes. 2012; 2012: 879151. doi: $10.1155 / 2012 / 879151$.

58. Salazar N, Gueimonde M, Hernandez-Barranco AM, Ruas-Madiedo P, de los Reyes-Gavilan CG. Exopolysaccharides produced by intestinal Bifidobacterium strains act as fermentable substrates for human intestinal bacteria. Appl Environ Microbiol. 2008; 74(15): 4737-45. doi: 10.1128/AEM.00325-08.

59. Brown AJ, Goldsworthy SM, Barnes AA, Eilert MM, Tcheang L, Daniels D, et al. The Orphan G protein-coupled receptors GPR41 and GPR43 are activated by propionate and other short chain carboxylic acids. J Biol Chem. 2003; 278(13): 11312-11319.

60. Le Poul E, Loison C, Struyf S, Springael JY, Lannoy V, Decobecq ME, et al. Functional characterization of human receptors for short chain fatty acids and their role in polymorphonuclear cell activation. J Biol Chem. 2003; 278(28): 25481-25489.

61. Nilsson NE, Kotarsky K, Owman C, Olde B. Identification of a free fatty acid receptor, FFA2R, expressed on leukocytes and activated by shortchain fatty acids. Biochem Biophys Res Commun. 2003; 303(4): 104752 .

62. Ge H, Li X, Weiszmann J, Wang P, Baribault H, Chen JL, et al. Activation of $\mathrm{G}$ protein-coupled receptor 43 in adipocytes leads to inhibition of lipolysis and suppression of plasma free fatty acids. Endocrinology. 2008; 149(9): 4519-26. doi: 10.1210/en.2008-0059.

63.Xiong Y, Miyamoto N, Shibata K, Valasek MA, Motoike T, Kedzierski $\mathrm{RM}$, et al. Short-chain fatty acids stimulate leptin production in adipocytes through the G protein-coupled receptor GPR41. Proc Natl Acad Sci U S A. 2004; 101(4): 1045-50.

64. Miyauchi S, Hirasawa A, Ichimura A, Hara T, Tsujimoto G. New 
frontiers in gut nutrient sensor research: free fatty acid sensing in the gastrointestinal tract. J Pharmacol Sci. 2010; 112(1): 19-24.

65. Karaki S, Mitsui R, Hayashi H, Kato I, Sugiya H, Iwanaga T, et al. Shortchain fatty acid receptor, GPR43, is expressed by enteroendocrine cells and mucosal mast cells in rat intestine. Cell Tissue Res. 2006; 324(3): 353-360.

66. de La Serre CB, de Lartigue G, Raybould HE. Chronic exposure to Low dose bacterial lipopolysaccharide inhibits leptin signaling in vagal afferent neurons. Physiol Behav. 2015; 139: 188-94. doi: 10.1016/j. physbeh.2014.10.032.

67. Cani PD, Amar J, Iglesias MA, Poggi M, Knauf C, Bastelica D, et al. Metabolic endotoxemia initiates obesity and insulin resistance. Diabetes. 2007; 56(7): 1761-72.

68. Cani PD, Neyrinck AM, Fava F, Knauf C, Burcelin RG, Tuohy KM, et al. Selective increases of bifidobacteria in gut microflora improve highfat-diet-induced diabetes in mice through a mechanism associated with endotoxaemia. Diabetologia. 2007; 50(11): 2374-83.

69. Hanstock TL, Mallet PE, Clayton EH. Increased plasma d-lactic acid associated with impaired memory in rats. Physiol Behav. 2010; 101(5): 653-9. doi: 10.1016/j.physbeh.2010.09.018.

70. Tana C, Umesaki Y, Imaoka A, Handa T, Kanazawa M, Fukudo s. Altered profiles of intestinal microbiota and organic acids may be the origin of symptoms in irritable bowel syndrome. Neurogastroenterol Motil. 2010; 22(5): 512-9, e114-5. doi: 10.1111/j.1365-2982.2009.01427.x.

71. Ledochowski M, Widner B, Sperner-Unterweger B, Propst T, Vogel W, Fuchs D. Carbohydrate malabsorption syndromes and early signs of mental depression in females. Dig Dis Sci. 2000; 45(7): 1255-9.

72. Aklujkar M, Risso C, Smith J, Beaulieu D, Dubay R, Giloteaux L, et al. Anaerobic degradation of aromatic amino acids by the hyperthermophilic archaeon Ferroglobus placidus. Microbiology. 2014; 160 (Pt 12): 2694-709. doi: 10.1099/mic.0.083261-0.

73. Ruddick JP, Evans AK, Nutt DJ, Lightman SL, Rook GA, Lowry CA Tryptophan metabolism in the central nervous system: medical implications. Expert Rev Mol Med. 2006; 8(20): 1-27.

74. Clarke G, Fitzgerald P, Cryan JF, Cassidy EM, Quigley EM, Dinan TG. Tryptophan degradation in irritable bowel syndrome: evidence of indoleamine 2,3-dioxygenase activation in a male cohort. BMC Gastroenterol. 2009; 9: 6. doi: 10.1186/1471-230X-9-6.

75. Orlikov AB, Prakhye IB, Ryzov IV. Kynurenine in blood plasma and DST in patients with endogenous anxiety and endogenous depression. Biol Psychiatry. 1994; 36(2): 97-102.

76. Myint AM. Kynurenines: from the perspective of major psychiatric disorders. FEBS J. 2012; 279(8): 1375-85. doi: 10.1111/j.17424658.2012.08551.x.

77. Valladares R, Bojilova L, Potts AH, Cameron E, Gardner C, Lorca G, et al. Lactobacillus johnsonii inhibits indoleamine 2,3-dioxygenase and alters tryptophan metabolite levels in BioBreeding rats. FASEB J. 2013; 27(4): 1711-20. doi: 10.1096/fj.12-223339.

78. El Aidy S, Kunze W, Bienenstock J, Kleerebezem M. The microbiota and the gut-brain axis: insights from the temporal and spatial mucosal alterations during colonisation of the germfree mouse intestine. Benef Microbes. 2012; 3(4): 251-9. doi: 10.3920/BM2012.0042.

79. Savignac HM, Corona G, Mills H, Chen L, Spencer JP, Tzortzis G, et al. Prebiotic feeding elevates central brain derived neurotrophic factor, $\mathrm{N}$-methyl-D-aspartate receptor subunits and D-serine. Neurochem Int. 2013; 63(8): 756-64. doi: 10.1016/j.neuint.2013.10.006.
80. Forsythe P, Bienenstock J. Immunomodulation by commensal and probiotic bacteria. Immunol Invest. 2010; 39(4-5): 429-48. doi: 10.3109/08820131003667978.

81. Duerkop BA, Vaishnava S, Hooper LV. Immune responses to the microbiota at the intestinal mucosal surface. Immunity. 2009; 31(3): 368-76. doi: 10.1016/j.immuni.2009.08.009.

82. Mogensen TH. Pathogen recognition and inflammatory signaling in innate immune defenses. Clin Microbiol Rev. 2009; 22(2): 240-73, Table of Contents. doi: 10.1128/CMR.00046-08.

83. Barton GM, Kagan JC. A cell biological view of Toll-like receptor function: regulation through compartmentalization. Nat Rev Immunol. 2009; 9(8): 535-42. doi: 10.1038/nri2587.

84. Ting JP, Lovering RC, Alnemri ES, Bertin J, Boss JM, Davis BK, et al. The NLR gene family: a standard nomenclature. Immunity. 2008; 28(3): 285-7. doi: 10.1016/j.immuni.2008.02.005.

85. Barajon I, Serrao G, Arnaboldi F, Opizzi E, Ripamonti G, Balsari A, et al. Toll-like receptors 3,4 , and 7 are expressed in the enteric nervous system and dorsal root ganglia. J Histochem Cytochem. 2009; 57(11): 1013-23. doi: 10.1369/jhc.2009.953539.

86. Brun P, Giron MC, Qesari M, Porzionato A, Caputi V, Zoppellaro C, et al. Toll-like receptor 2 regulates intestinal inflammation by controlling integrity of the enteric nervous system. Gastroenterology. 2013; 145(6): 1323-33. doi: 10.1053/j.gastro.2013.08.047.

87. de La Serre CB, Ellis CL, Lee J, Hartman AL, Rutledge JC, Raybould HE. Propensity to high-fat diet-induced obesity in rats is associated with changes in the gut microbiota and gut inflammation. Am J Physiol Gastrointest Liver Physiol. 2010; 299(2): G440-8. doi: 10.1152/ ajpgi.00098.2010.

88. Cario E, Podolsky DK. Intestinal epithelial TOLLerance versus inTOLLerance of commensals. Mol Immunol. 2005; 42(8): 887-93.

89. Schertzer JD, Tamrakar AK, Magalhaes JG, Pereira S, Bilan PJ, Fullerton MD, et al. NOD1 activators link innate immunity to insulin resistance. Diabetes. 2011; 60(9): 2206-15. doi: 10.2337/db11-0004.

90. Ismail AS, Behrendt CL, Hooper LV. Reciprocal interactions between commensal bacteria and gamma delta intraepithelial lymphocytes during mucosal injury. J Immunol. 2009; 182(5): 3047-54. doi: 10.4049/jimmunol.0802705.

91. Atarashi K, Nishimura J, Shima T, Umesaki Y, Yamamoto M, Onoue M, et al. ATP drives lamina propria $\mathrm{T}(\mathrm{H}) 17$ cell differentiation. Nature. 2008; 455(7214): 808-12. doi: 10.1038/nature07240.

92. Ivanov, II, Frutos Rde L, Manel N, Yoshinaga K, Rifkin DB, Sartor RB, et al. Specific microbiota direct the differentiation of IL-17-producing T-helper cells in the mucosa of the small intestine. Cell Host Microbe. 2008; 4(4): 337-49. doi: 10.1016/j.chom.2008.09.009.

93. Kinnebrew MA, Ubeda C, Zenewicz LA, Smith N, Flavell RA, Pamer EG. Bacterial flagellin stimulates Toll-like receptor 5-dependent defense against vancomycin-resistant Enterococcus infection. J Infect Dis. 2010; 201(4): 534-43. doi: 10.1086/650203.

94. Mazmanian SK, Round JL, Kasper DL. A microbial symbiosis factor prevents intestinal inflammatory disease. Nature. 2008; 453(7195): 620-5. doi: 10.1038/nature07008.

95. Falk PG, Hooper LV, Midtvedt T, Gordon JI. Creating and maintaining the gastrointestinal ecosystem: what we know and need to know from gnotobiology. Microbiol Mol Biol Rev. 1998; 62(4): 1157-70.

96. Macpherson AJ, Harris NL. Interactions between commensal intestinal bacteria and the immune system. Nat Rev Immunol. 2004; 4(6): 478- 
85.

97. Imaoka A, Matsumoto S, Setoyama H, Okada Y, Umesaki Y. Proliferative recruitment of intestinal intraepithelial lymphocytes after microbial colonization of germ-free mice. Eur J Immunol. 1996;26(4): 945-8.

98. Umesaki Y, Setoyama H, Matsumoto S, Okada Y. Expansion of alpha beta T-cell receptor-bearing intestinal intraepithelial lymphocytes after microbial colonization in germ-free mice and its independence from thymus. Immunology. 1993; 79(1): 32-7.

99. Lundin A, Bok CM, Aronsson L, Bjorkholm B, Gustafsson JA, Pott S, et al. Gut flora, Toll-like receptors and nuclear receptors: a tripartite communication that tunes innate immunity in large intestine. Cell Microbiol. 2008; 10(5): 1093-103.

100. Matsumoto S, Setoyama H, Umesaki Y. Differential induction of major histocompatibility complex molecules on mouse intestine by bacterial colonization. Gastroenterology. 1992; 103(6): 1777-82.

101. Muzio M, Bosisio D, Polentarutti N, D’Amico G, Stoppacciaro A, Mancinelli R, et al. Differential expression and regulation of toll-like receptors (TLR) in human leukocytes: selective expression of TLR3 in dendritic cells. J Immunol. 2000; 164(11): 5998-6004.

102. Vijay-Kumar M, Aitken JD, Carvalho FA, Cullender TC, Mwangi S Srinivasan S, et al. Metabolic syndrome and altered gut microbiota in mice lacking Toll-like receptor 5. Science. 2010; 328(5975): 22831. doi: 10.1126/science.1179721.

103. Dethlefsen L, McFall-Ngai M, Relman DA. An ecological and evolutionary perspective on human-microbe mutualism and disease. Nature. 2007; 449(7164): 811-818.

104. Rook GA. Review series on helminths, immune modulation and the hygiene hypothesis: the broader implications of the hygiene hypothesis. Immunology. 2009; 126(1): 3-11. doi: 10.1111/j.13652567.2008.03007.x

105. Feingold KR, Staprans I, Memon RA, Moser AH, Shigenaga JK, Doerrler W, et al. Endotoxin rapidly induces changes in lipid metabolism that produce hypertriglyceridemia: low doses stimulate hepatic triglyceride production while high doses inhibit clearance. J Lipid Res. 1992; 33(12): 1765-76.

106. Maitra U, Gan L, Chang S, Li L. Low-dose endotoxin induces inflammation by selectively removing nuclear receptors and activating CCAAT/enhancer-binding protein delta. J Immunol. 2011; 186(7): 4467-73. doi: 10.4049/jimmunol.1003300.

107. O’Mahony L, McCarthy J, Kelly P, Hurley G, Luo F, Chen K, et al. Lactobacillus and bifidobacterium in irritable bowel syndrome: symptom responses and relationship to cytokine profiles. Gastroenterology. 2005; 128(3): 541-551.

108. Desbonnet L, Garrett L, Clarke G, Bienenstock J, Dinan T. The probiotic Bifidobacteria infantis: An assessment of potential antidepressant properties in the rat. J Psychiatr Res. 2008; 43(2): 164-74. doi: 10.1016/j.jpsychires.2008.03.009.

109. Desbonnet L, Garrett L, Clarke G, Kiely B, Cryan JF, Dinan TG. Effects of the probiotic Bifidobacterium infantis in the maternal separation model of depression. Neuroscience. 2010; 170(4): 1179-88. doi: 10.1016/j.neuroscience.2010.08.005.

110. Honda K, Takeda K. Regulatory mechanisms of immune responses to intestinal bacteria. Mucosal Immunol. 2009; 2(3): 187-96. doi: 10.1038/mi.2009.8.

111. Lotrich FE, El-Gabalawy H, Guenther LC, Ware CF. The role of inflammation in the pathophysiology of depression: different treatments and their effects. J Rheumatol Suppl. 2011; 88: 48-54. doi: 10.3899/jrheum.110903.

112. de Lartigue G. Putative roles of neuropeptides in vagal afferent signaling. Physiol Behav. 2014; 136: 155-69. doi: 10.1016/j. physbeh.2014.03.011.

113. Chang HY, Mashimo H, Goyal RK. Musings on the wanderer: what's new in our understanding of vago-vagal reflex? IV. Current concepts of vagal efferent projections to the gut. Am J Physiol Gastrointest Liver Physiol. 2003; 284(3): G357-366.

114. Clarke MB, Hughes DT, Zhu C, Boedeker EC, Sperandio V. The QseC sensor kinase: a bacterial adrenergic receptor. Proc Natl Acad Sci U S A. 2006 ; 103(27): 10420-5.

115. Schwartz MW, Woods SC, Porte D, Jr., Seeley RJ, Baskin DG. Central nervous system control of food intake. Nature. 2000; 404(6778): 661-71.

116. Kashyap PC, Marcobal A, Ursell LK, Larauche M, Duboc H, Earle KA, et al. Complex interactions among diet, gastrointestinal transit, and gut microbiota in humanized mice. Gastroenterology. 2013; 144(5): 967-77. doi: 10.1053/j.gastro.2013.01.047.

117. Pflughoeft KJ, Versalovic J. Human microbiome in health and disease. Annu Rev Pathol. 2012; 7: 99-122. doi: 10.1146/annurevpathol-011811-132421.

118. Bailey MT, Dowd SE, Galley JD, Hufnagle AR, Allen RG, Lyte M. Exposure to a social stressor alters the structure of the intestinal microbiota: implications for stressor-induced immunomodulation. Brain Behav Immun. 2011; 25(3): 397-407. doi: 10.1016/j. bbi.2010.10.023.

119. Bailey MT, Engler H, Sheridan JF. Stress induces the translocation of cutaneous and gastrointestinal microflora to secondary lymphoid organs of C57BL/6 mice. J Neuroimmunol. 2006; 171(1-2): 29-37.

120. Santos J, Yang PC, Soderholm JD, Benjamin M, Perdue MH. Role of mast cells in chronic stress induced colonic epithelial barrier dysfunction in the rat. Gut. 2001; 48(5): 630-6.

121. O'Mahony SM, Marchesi JR, Scully P, Codling C, Ceolho AM, Quigley EM, et al. Early life stress alters behavior, immunity, and microbiota in rats: implications for irritable bowel syndrome and psychiatric illnesses. Biol Psychiatry. 2009; 65(3): 263-7. doi: 10.1016/j. biopsych.2008.06.026.

122. Ma J, Prince AL, Bader D, Hu M, Ganu R, Baquero K, et al. Highfat maternal diet during pregnancy persistently alters the offspring microbiome in a primate model. Nat Commun. 2014; 5: 3889. doi: $10.1038 /$ ncomms4889.

123. Organization. FWFaAOWH. Evaluation of Health and Nutritional Properties of Probiotics in Food. 2001.

124. Lahtinen SJ, Boyle RJ, Kivivuori S, Oppedisano F, Smith KR, RobinsBrowne R, et al. Prenatal probiotic administration can influence Bifidobacterium microbiota development in infants at high risk of allergy. J Allergy Clin Immunol. 2009; 123(2): 499-501. doi: 10.1016/j.jaci.2008.11.034.

125. Corr SC, Hill C, Gahan CG. Understanding the mechanisms by which probiotics inhibit gastrointestinal pathogens. Adv Food Nutr Res. 2009; 56: 1-15. doi: 10.1016/S1043-4526(08)00601-3.

126. Ohland CL, Macnaughton WK. Probiotic bacteria and intestinal epithelial barrier function. Am J Physiol Gastrointest Liver Physiol. 2010; 298(6): G807-19. doi: 10.1152/ajpgi.00243.2009.

127. Cotter PD, Hill C, Ross RP. Bacteriocins: developing innate immunity 
for food. Nat Rev Microbiol. 2005; 3(10): 777-88.

128. Asahara T, Shimizu K, Nomoto K, Hamabata T, Ozawa A, Takeda Y. Probiotic bifidobacteria protect mice from lethal infection with Shiga toxin-producing Escherichia coli 0157:H7. Infect Immun. 2004; 72(4): 2240-7.

129. Gopal PK, Prasad J, Smart J, Gill HS. In vitro adherence properties of Lactobacillus rhamnosus DR20 and Bifidobacterium lactis DR10 strains and their antagonistic activity against an enterotoxigenic Escherichia coli. Int J Food Microbiol. 2001; 67(3): 207-16.

130. Corr SC, Li Y, Riedel CU, O’Toole PW, Hill C, Gahan CG. Bacteriocin production as a mechanism for the antiinfective activity of Lactobacillus salivarius UCC118. Proc Natl Acad Sci U S A. 2007; 104(18): 7617-21.

131. Corr SC, Gahan CG, Hill C. Impact of selected Lactobacillus and Bifidobacterium species on Listeria monocytogenes infection and the mucosal immune response. FEMS Immunol Med Microbiol. $2007 ; 50(3): 380-8$.

132. O'Hara AM, O’Regan P, Fanning A, O’Mahony C, Macsharry J, Lyons $A$, et al. Functional modulation of human intestinal epithelial cell responses by Bifidobacterium infantis and Lactobacillus salivarius. Immunology. 2006; 118(2): 202-215.

133. Di Giacinto C, Marinaro M, Sanchez M, Strober W, Boirivant M Probiotics ameliorate recurrent Th1-mediated murine colitis by inducing IL-10 and IL-10-dependent TGF-beta-bearing regulatory cells. J Immunol. 2005; 174(6): 3237-46.

134. Silva AM, Barbosa FH, Duarte R, Vieira LQ, Arantes RM, Nicoli JR. Effect of Bifidobacterium longum ingestion on experimental salmonellosis in mice. J Appl Microbiol. 2004; 97(1): 29-37.

135. Menard S, Candalh C, Bambou JC, Terpend K, Cerf-Bensussan N Heyman M. Lactic acid bacteria secrete metabolites retaining antiinflammatory properties after intestinal transport. Gut. 2004; 53(6): 821-828.

136. Fukushima Y, Kawata Y, Hara H, Terada A, Mitsuoka T. Effect of a probiotic formula on intestinal immunoglobulin A production in healthy children. Int J Food Microbiol. 1998; 42(1-2): 39-44.

137. Galdeano CM, Perdigon G. The probiotic bacterium Lactobacillus casei induces activation of the gut mucosal immune system through innate immunity. Clin Vaccine Immunol. 2006; 13(2): 219-26.

138. Sherman PM, Johnson-Henry KC, Yeung HP, Ngo PS, Goulet J, Tompkins TA. Probiotics reduce enterohemorrhagic Escherichia coli 0157:H7- and enteropathogenic E. coli 0127:H6-induced changes in polarized T84 epithelial cell monolayers by reducing bacterial adhesion and cytoskeletal rearrangements. Infect Immun. 2005; 73(8): 5183-8.

139. Tsai CC, Hsih HY, Chiu HH, Lai YY, Liu JH, Yu B, et al. Antagonistic activity against Salmonella infection in vitro and in vivo for two Lactobacillus strains from swine and poultry. Int J Food Microbiol. 2005; 102(2): 185-94.

140. Johnson-Henry KC, Hagen KE, Gordonpour M, Tompkins TA, Sherman PM. Surface-layer protein extracts from Lactobacillus helveticus inhibit enterohaemorrhagic Escherichia coli 0157:H7 adhesion to epithelial cells. Cell Microbiol. 2007; 9(2): 356-67.

141. Mattar AF, Teitelbaum DH, Drongowski RA, Yongyi F, Harmon CM, Coran AG. Probiotics up-regulate MUC-2 mucin gene expression in a Caco-2 cell-culture model. Pediatr Surg Int. 2002; 18(7): 586-90.

142. Mack DR, Ahrne S, Hyde L, Wei S, Hollingsworth MA. Extracellular
MUC3 mucin secretion follows adherence of Lactobacillus strains to intestinal epithelial cells in vitro. Gut. 2003; 52(6): 827-33.

143. Furrie E, Macfarlane S, Kennedy A, Cummings JH, Walsh SV, O'neil DA, et al. Synbiotic therapy (Bifidobacterium longum/Synergy 1) initiates resolution of inflammation in patients with active ulcerative colitis: a randomised controlled pilot trial. Gut. 2005; 54(2): 242-9.

144. Schlee M, Harder J, Koten B, Stange EF, Wehkamp J, Fellermann K. Probiotic lactobacilli and VSL\#3 induce enterocyte beta-defensin 2. Clin Exp Immunol. 2008; 151(3): 528-35. doi: 10.1111/j.13652249.2007.03587.x

145. Park DY, Ahn YT, Park SH, Huh CS, Yoo SR, Yu R, et al. Supplementation of Lactobacillus curvatus HY7601 and Lactobacillus plantarum KY1032 in diet-induced obese mice is associated with gut microbial changes and reduction in obesity. PLoS One. 2013; 8(3): e59470. doi: 10.1371/journal.pone.0059470.

146. Musso G, Gambino R, Cassader M. Interactions between gut microbiota and host metabolism predisposing to obesity and diabetes. Annu Rev Med. 2011; 62: 361-80. doi: 10.1146/annurevmed-012510-175505.

147. Kang JH, Yun SI, Park MH, Park JH, Jeong SY, Park HO. Anti-obesity effect of Lactobacillus gasseri BNR17 in high-sucrose diet-induced obese mice. PLoS One. 2013; 8(1): e54617. doi: 10.1371/journal. pone.0054617.

148. Kim SW, Park KY, Kim B, Kim E, Hyun CK. Lactobacillus rhamnosus GG improves insulin sensitivity and reduces adiposity in high-fat diet-fed mice through enhancement of adiponectin production. Biochem Biophys Res Commun. 2013 Feb 8; 431(2): 258-63. doi: 10.1016/j.bbrc.2012.12.121.

149. Groeger D, O’Mahony L, Murphy EF, Bourke JF, Dinan TG, Kiely B, et al. Bifidobacterium infantis 35624 modulates host inflammatory processes beyond the gut. Gut Microbes. 2013; 4(4): 325-39. doi: 10.4161/gmic.25487.

150. Bravo JA, Julio-Pieper M, Forsythe P, Kunze W, Dinan TG, Bienenstock $\mathrm{J}$, et al. Communication between gastrointestinal bacteria and the nervous system. Curr Opin Pharmacol. 2012; 12(6): 667-72. doi: 10.1016/j.coph.2012.09.010.

151. Forsythe P, Sudo N, Dinan T, Taylor VH, Bienenstock J. Mood and gut feelings. Brain Behav Immun. 2010; 24(1): 9-16. doi: 10.1016/j. bbi.2009.05.058.

152. Yan F, Polk DB. Probiotic bacterium prevents cytokine-induced apoptosis in intestinal epithelial cells. J Biol Chem. 2002; 277(52): 50959-65.

153. Lammers KM, Brigidi P, Vitali B, Gionchetti P, Rizzello F, Caramelli E, et al. Immunomodulatory effects of probiotic bacteria DNA: IL-1 and IL-10 response in human peripheral blood mononuclear cells. FEMS Immunol Med Microbiol. 2003; 38(2): 165-72.

154. Ramiah K, van Reenen CA, Dicks LM. Surface-bound proteins of Lactobacillus plantarum 423 that contribute to adhesion of Caco2 cells and their role in competitive exclusion and displacement of Clostridium sporogenes and Enterococcus faecalis. Res Microbiol. 2008; 159(6): 470-5. doi: 10.1016/j.resmic.2008.06.002.

155. Alesci S, Martinez PE, Kelkar S, Ilias I, Ronsaville DS, Listwak SJ, et al. Major depression is associated with significant diurnal elevations in plasma interleukin-6 levels, a shift of its circadian rhythm, and loss of physiological complexity in its secretion: clinical implications. J Clin Endocrinol Metab. 2005; 90(5): 2522-30.

156. Miller AH, Maletic V, Raison CL. Inflammation and its 
discontents: the role of cytokines in the pathophysiology of major depression. Biol Psychiatry. 2009; 65(9): 732-41. doi: 10.1016/j. biopsych.2008.11.029.

157. Karimi K, Inman MD, Bienenstock J, Forsythe P. Lactobacillus reuteri-induced regulatory $\mathrm{T}$ cells protect against an allergic airway response in mice. Am J Respir Crit Care Med. 2009; 179(3): 186-93. doi: 10.1164/rccm.200806-9510C.

158. Bisson JF, Hidalgo S, Rozan P, Messaoudi M. Preventive effects of different probiotic formulations on travelers' diarrhea model in wistar rats : preventive effects of probiotics on TD. Dig Dis Sci. 2010; 55(4): 911-9. doi: 10.1007/s10620-009-0822-4.

159. Komatsuzaki N, Nakamura T, Kimura T, Shima J. Characterization of glutamate decarboxylase from a high gamma-aminobutyric acid (GABA)-producer, Lactobacillus paracasei. Biosci Biotechnol Biochem. 2008; 72(2): 278-85.

160. Martin FP, Rezzi S, Pere-Trepat E, Kamlage B, Collino S, Leibold E, et al. Metabolic effects of dark chocolate consumption on energy, gut microbiota, and stress-related metabolism in free-living subjects. J Proteome Res. 2009; 8(12): 5568-79. doi: 10.1021/pr900607v.

161. Messaoudi M, Lalonde R, Violle N, Javelot H, Desor D, Nejdi A et al. Assessment of psychotropic-like properties of a probiotic formulation (Lactobacillus helveticus R0052 and Bifidobacterium longum R0175) in rats and human subjects. Br J Nutr. 2011; 105(5): 755-64. doi: 10.1017/S0007114510004319.

162. Gibson GR, Roberfroid MB. Dietary modulation of the human colonic microbiota: introducing the concept of prebiotics. J Nutr. 1995; 125(6): 1401-12.

163. Everard A, Lazarevic V, Derrien M, Girard M, Muccioli GG, Neyrinck AM, et al. Responses of Gut Microbiota and Glucose and Lipid Metabolism to Prebiotics in Genetic Obese and Diet-Induced LeptinResistant Mice. Diabetes. 2011; 60(11): 2775-86. doi: 10.2337/ db11-0227.

164. Everard A, Belzer C, Geurts L, Ouwerkerk JP, Druart C, Bindels LB, et al. Cross-talk between Akkermansia muciniphila and intestinal epithelium controls diet-induced obesity. Proc Natl Acad Sci U S A 2013; 110(22): 9066-71. doi: 10.1073/pnas.1219451110.

165. Bomhof MR, Saha DC, Reid DT, Paul HA, Reimer RA. Combined effects of oligofructose and Bifidobacterium animalis on gut microbiota and glycemia in obese rats. Obesity (Silver Spring). 2014; 22(3): 763-71. doi: 10.1002/oby.20632.

166. Parnell JA, Reimer RA. Weight loss during oligofructose supplementation is associated with decreased ghrelin and increased peptide YY in overweight and obese adults. Am J Clin Nutr. 2009; 89(6): 1751-9. doi: 10.3945/ajcn.2009.27465.

167. Erejuwa 00, Sulaiman SA, Wahab MS, Sirajudeen KN, Salleh MS, Gurtu S. Glibenclamide or metformin combined with honey improves glycemic control in streptozotocin-induced diabetic rats. Int J Biol Sci. 2011; 7 (2): 244-52.

168. Kajimoto Y, Kaneto H. Role of oxidative stress in pancreatic beta-cell dysfunction. Ann N Y Acad Sci. 2004; 1011: 168-76.

169. Grankvist K, Marklund SL, Taljedal IB. CuZn-superoxide dismutase, $\mathrm{Mn}$-superoxide dismutase, catalase and glutathione peroxidase in pancreatic islets and other tissues in the mouse. Biochem J. 1981; 199(2): 393-8.
170. Erejuwa 00, Sulaiman SA, Wahab MS, Sirajudeen KN, Salleh MS, Gurtu S. Antioxidant protection of Malaysian tualang honey in pancreas of normal and streptozotocin-induced diabetic rats. Ann Endocrinol (Paris). 2010; 71(4): 291-6. doi: 10.1016/j.ando.2010.03.003.

171. Schmidt K, Cowen P, Harmer C, Tzortzis G, Errington S, Burnet PW. Prebiotic intake reduces the waking cortisol response and alters emotional bias in healthy volunteers. Psychopharmacology (Berl). 2014.

172. Guo B, Harstall C, Louie T, Veldhuyzen van Zanten S, Dieleman LA. Systematic review: faecal transplantation for the treatment of Clostridium difficile-associated disease. Aliment Pharmacol Ther. 2012; 35(8): 865-75. doi: 10.1111/j.1365-2036.2012.05033.x.

173. Vrieze A, Van Nood E, Holleman F, Salojarvi J, Kootte RS, Bartelsman $\mathrm{JF}$, et al. Transfer of intestinal microbiota from lean donors increases insulin sensitivity in individuals with metabolic syndrome. Gastroenterology. 2012; 143(4): 913-6.e7. doi: 10.1053/j. gastro.2012.06.031.

174. Anil Ananthaswamy. Faecal transplant eases symptoms of Parkinson's. New Scientist. 2011; 209(2796): 8-9.

175. Rajilic-Stojanovic M, Biagi E, Heilig HG, Kajander K, Kekkonen RA, Tims S, et al. Global and deep molecular analysis of microbiota signatures in fecal samples from patients with irritable bowel syndrome. Gastroenterology. 2011; 141(5): 1792-801. doi: 10.1053/j.gastro.2011.07.043.

176. Finegold SM, Molitoris D, Song Y, Liu C, Vaisanen ML, Bolte E, et al. Gastrointestinal microflora studies in late-onset autism. Clin Infect Dis. 2002; 35: S6-s16.

177. Stefater MA, Kohli R, Inge TH. Advances in the surgical treatment of morbid obesity. Mol Aspects Med. 2013; 34(1): 84-94. doi: 10.1016/j.mam.2012.10.006.

178. Kashyap SR, Bhatt DL, Wolski K, Watanabe RM, Abdul-Ghani M, Abood B, et al. Metabolic effects of bariatric surgery in patients with moderate obesity and type 2 diabetes: analysis of a randomized control trial comparing surgery with intensive medical treatment. Diabetes Care. 2013; 36(8): 2175-82. doi: 10.2337/dc12-1596.

179. Zhang H, DiBaise JK, Zuccolo A, Kudrna D, Braidotti M, Yu Y, et al. Human gut microbiota in obesity and after gastric bypass. Proc Natl Acad Sci U S A. 2009; 106(7): 2365-70. doi: 10.1073/ pnas. 0812600106 .

180. Kong LC, Tap J, Aron-Wisnewsky J, Pelloux V, Basdevant A, Bouillot $\mathrm{JL}$, et al. Gut microbiota after gastric bypass in human obesity: increased richness and associations of bacterial genera with adipose tissue genes. Am J Clin Nutr. 2013; 98(1): 16-24. doi: 10.3945/ ajcn.113.058743.

181. Li JV, Ashrafian H, Bueter M, Kinross J, Sands C, le Roux CW, et al. Metabolic surgery profoundly influences gut microbial-host metabolic cross-talk. Gut. 2011; 60(9): 1214-23. doi: 10.1136/ gut.2010.234708.

182. Furet JP, Kong LC, Tap J, Poitou C, Basdevant A, Bouillot JL, et al. Differential adaptation of human gut microbiota to bariatric surgery-induced weight loss: links with metabolic and low-grade inflammation markers. Diabetes. 2010; 59(12): 3049-57. doi: $10.2337 / \mathrm{db} 10-0253$. 